\title{
MGNREGA and Financial Inclusion - An Inter-District Analysis of Odisha
}

\author{
Minati Sahoo \\ Centre of Economics, School of Development Studies, Central University Of Odisha, India
}

\begin{abstract}
The study attempts to have an inter-district analysis of the performance of MGNREGA in Odisha. Among 23 states, Odisha is having an index of financial inclusion value of 0.2 and is at 15th rank. Thus the extent of financial inclusion is found to be significantly low in Odisha. Financial inclusion is the key to empowerment of poor, underprivileged and low skilled rural households as they compose 70 percentage of Indian population. Financial Inclusion can truly lift the financial condition and improve the standards of lives of the poor and the disadvantaged. To fasten the pace of financial inclusion, the Government of India in 2008 declared that wage payments, under the Mahatma Gandhi National Rural Employment Guarantee Act, the world's largest rural public works programme, would be made through banks and post offices. As MGNREGA is a widely discussed public policy and knowledge about it is the need of the hour, the present paper will analyze how the scheme is helping in promoting financial inclusion via wage payment through banks and post offices in Odisha. It will also highlight some of the problems that are encountered when banks and post offices are used as a means for wage payment to accelerate the speed of financial inclusion and remedial measures that could be taken to tackle these problems.
\end{abstract}

Keywords: Empowerment, Financial Inclusion, Public Policy, Rural Households, Wage Payment.

\section{Introduction}

“...we have to ensure inclusive and equitable growth, we need to knit and integrate our rural areas.... We cannot allow India to be divided into two distinct zones."

Dr. Manmohan Singh

Inclusive growth has become almost an expression of common usage now. Inclusive growth attempts to bridge the various divides in an economy and society, between the rich and the poor, between the rural and urban population, and between one region and another. This is a formidable task. The process of growth has to be such that all sections of society benefit from the growth process and that is the essence of inclusive growth. One aspect of inclusive growth is financial inclusion. The process of financial inclusion is an attempt to bring within the ambit of the organized financial system the weaker and vulnerable sections of society. In more recent years the debate expanded to include the notion of financial "exclusion" as a barrier to economic development and the need to build inclusive financial systems [1].

The concept of financial inclusion has a special significance for a growing economy like India as bringing the large segment of the productive sectors of the economy under formal financial network could unleash their creative capacities besides augmenting domestic demand on a sustainable basis driven by income and consumption growth from such sectors. According to Rangarajan Committee Report, 2008 financial inclusion can be defined as "the delivery of credit and other financial services at an affordable cost to the vast sections of the disadvantaged and low income groups". The various financial services include savings, credit, insurance and payments and remittance facilities. The objective of financial inclusion is to extend the scope of activities of the organized financial system to include within its ambit people with low incomes. Through graduated credit, attempts must be made to lift the poor from one level to another so that they come out of poverty. Access to basic financial services such as savings, payments and credit can make a substantial positive difference in improving poor people's lives [2, 3].Financial inclusion efforts do have multiplier effect on the economy as a whole through higher savings pooled from the vast segment of the bottom of the pyramid population by providing access to formal savings arrangement resulting in expansion in credit and investment by banks. Deeper engagements of the under-banked population in the economy through the formal financial system could lead to improvement of their financial conditions and living standards, enabling them to create financial assets, generate income and build resilience to meet macro-economic and livelihood shocks. Governments will also immensely benefits by way of efficient and leakage-proof transfer of vast amounts of welfare benefits to the targeted, disadvantaged groups of population. Thus section two will discuss about the importance and background of the study. In section three, an inter district analysis of performance of MGNREGA in achieving Financial Inclusion is discussed. While Section four deals with the issues relating to payment of wages through bank/post office with some policy prescription, Section fives concludes the paper. 


\section{Background Of Study And Objectives}

Financial inclusion can be a key to empowerment of poor, underprivileged and low skilled rural households. It can truly lift the financial condition and improve the standards of lives of the poor and the disadvantaged. Access to affordable financial services, especially credit and insurance, enlarges livelihood opportunities through adoption of different economic activities. Better financial inclusion would lead to increasing economic activities and self/wage employment opportunities for rural households. As a result rural households will earn greater return /disposable income. A higher disposable income at the hands of rural households would lead to greater savings and would provide a wider deposit base to banks and other financial institutions to be helpful in undertaking variety of economic activities. Thus financial inclusion provides monetary fuel for economic growth and it is considered critical for achieving inclusive growth. The extent of financial exclusion in India is found to be higher as compared with many developed and some of the major emerging economies. The wide extent of financial exclusion in India is visible in the form of high population per bank branch and low proportion of the population having access to basic financial services like savings accounts, credit facilities, credit and debit cards. The following table 1 summarizes India's performance in the area of financial inclusion as compared with other developing as well as developed countries.

Table 1: Selected indicators of Financial Inclusion - Cross Country Analysis

\begin{tabular}{|c|c|c|c|c|}
\hline \multirow{3}{*}{ Country } & Number of & Number of & Bank & Bank \\
\hline & Branches & ATMs & credit & deposits \\
\hline & \multicolumn{2}{|c|}{ (per 100,000 adults) } & \multicolumn{2}{|c|}{ (as per cent of GDP) } \\
\hline India & 10.64 & 8.90 & 51.75 & 68.43 \\
\hline Austria & 15.17 & 114.09 & 49.43 & 37.22 \\
\hline Brazil & 46.15 & 119.63 & 40.28 & 53.26 \\
\hline France & 41.58 & 109.80 & 42.85 & 34.77 \\
\hline Mexico & 14.86 & 45.77 & 18.81 & 22.65 \\
\hline United States & 35.43 & $173.75^{*}$ & 46.83 & 57.78 \\
\hline Korea & 18.80 & $270.13^{\#}$ & 90.65 & 80.82 \\
\hline Afghanistan & 1.90 & 0.53 & 5.27 & 22.71 \\
\hline Philippines & 8.07 & 17.7 & 21.39 & 41.93 \\
\hline
\end{tabular}

Source: Financial Access Survey, IMF (http://fas.imf.org/ ) [4]

Note: Data pertains to 2011. For rows/cells indicated as “*' data pertains to 2009 and for “\#” data pertains to 2010.

Indian Council for Research on International Economic Relations (ICRIER) India has developed an index in the year 2007 on the parameters of banking penetration, availability of banking services and usage of banking system to measure the financial inclusion for the various countries. As per the ICRIER index India occupied the 38th rank in 81 country ranking. According to the value of the index, Indian States can be classified into three categories, i.e., states having high, low and medium extent of financial exclusion. Kerala, Maharashtra and Karnataka are some of the States having wider extent of financial inclusion as compared to other States of India. Tamil Nadu, Punjab, Andhra Pradesh, Himachal Pradesh, Sikkim and Haryana fall under the category of medium financial exclusion The following chart 1 shows that the extent of financial inclusion is found to be significantly low in North-Eastern and Eastern States, i.e., Assam, Nagaland, Manipur, Odisha, Bihar, West Bengal, etc.[5]

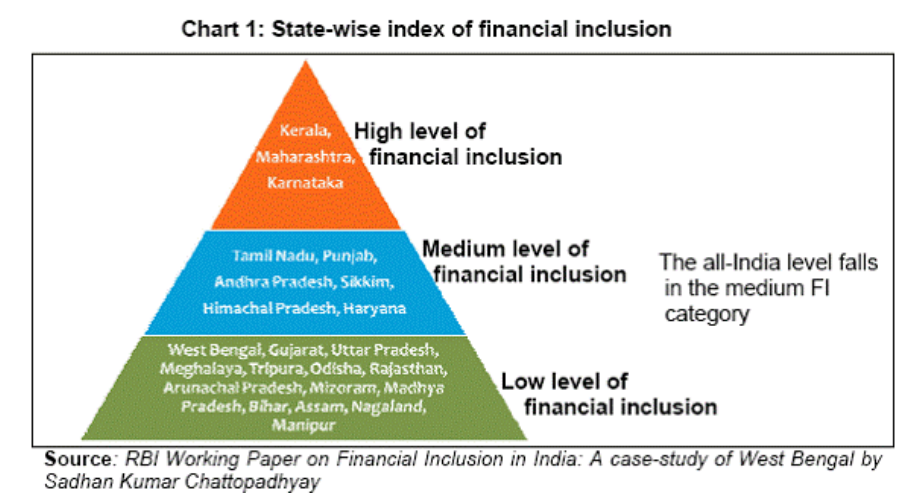

A World Bank-NCAER Survey on rural access to finance in 2003 indicates that 70 per cent of the rural poor do not have a bank account and 87 per cent have no access to credit from a formal source. Informal sector lenders remain a strong presence in rural India, delivering finance to the poor. RFAS, 2003 finds that 48 per cent of landless and marginal farmers borrowed from an informal source at least once in the past 12 months, at rates averaging 48 per cent per year. Another study by Diamond Management and Technology Consultants concluded 
that less than 20 per cent of rural Indians have access to formal financial services, and about 185 million "potentially bankable" people in rural India do not have a bank account

Financial inclusion can be construe in two ways. One is countering the exclusion from the payment system that is, not having an access to a bank account. The second is countering the exclusion from the formal financial services. The Indian approach in recent years has been to establish the basic right of every person to have access to a bank account. The Reserve Bank has therefore been pursuing a multi-pronged strategy for enhancing the outreach of financial services including the delivery channels across all sections. The entire spectrum of the financial system which comprises commercial banks, regional rural banks (RRBs), urban cooperative banks (UCBs), primary agricultural credit societies (PACS) and post offices is, therefore, geared for this purpose. Considering the importance of financial inclusion for the economy of the country the Government of India (Ministry of Finance), Reserve Bank of India and NABARD are adopting different measures for the financial inclusion. An attempt has been made in this direction by government when decision was made to make wage payments, under the Mahatma Gandhi National Rural Employment Guarantee Act, the world's largest rural public works programme, would be made through banks and post offices in 2008. With this background the objectives of study is to have an inter-district analysis of the performance of MGNREGA in Odisha and some policy measures which could further help this programme in achieving financial inclusion.

Thus how far this programme has fulfilled the dreams of government in achieving financial inclusion is discussed in next section.

\section{An Inter District Analysis Of Performance Of MGNREGA In Achieving Financial} Inclusion

It is well recognized that a large number of households and especially those in rural areas do not have bank accounts. To speed up the pace of financial inclusion, an attempt has been made in this direction by Mahatma Gandhi National Rural Employment Guarantee Programme which acknowledges the importance of Gandhi's dream of rural development in India that care they need and rights of the deprived class in a more coherent manner. It is a hundred percent centrally sponsored scheme, which provides rights-based framework of wage employment programme and makes the government legally bound to provide employment to adult members of rural household.

The Act got first introduced in 200 most backward districts of the country in Feb 2006. It was proposed to extend to the remaining districts only after 5 years, after seeing the popularity of the Act. But in the next year itself the Act was extended further to 130 more districts \& within a year after the Act got universalized by bringing the entire country under its horizon with the exception of districts that have a hundred percent urban population \& got soon named after Mahatma Gandhi $\left(2^{\text {nd }}\right.$ October 2009) to make the Act more reachable to the masses and thus it became Mahatma Gandhi National Rural Employment Guarantee Act (MGNREGA).

In the context of Odisha all the tribal dominated districts were covered from the very beginning. Indeed, Orissa has been projected as the first state in implementation of the MGNREGS, showing a total expenditure of more than Rs. 700 crores, a fund utilisation of $82.39 \%$, surpassing all the major states in percentage of expenditure against available funds in 2006-07. Even as the reports of 700 crores plus utilisation started coming out, it was puzzled to see the near non-existence, and non- impact of these achievements in the rural areas. In villages like Podabandh and Pudugusil in Rayagada district, people had worked and not received wages. Then, asked to sign on blank muster rolls before they could receive payment. In Kanheimunda in Nabrangpur, there were several discrepancies in the records in the job cards, and in the payment received. In a village like Tikarapada, in Koraput district, people had received more money than the number of days worked, but the much talked about e-records indicated that the muster roles showed 28 days, as against the 12 days of payment made. In actual fact, people had worked only 5 days [6]. There is very little in the Act to ensure that the laborer gets due payment after completion of the work.

In order to ensure timely payment to MGNREGA workers and to ensure financial inclusion in May 2008, the Government declared that wage payments, under the Mahatma Gandhi National Rural Employment Guarantee Act, the world's largest rural public works programme, would be made through banks and post offices. The percentage of people in a given area with access to a bank account is the typical measuring stick for breadth of financial services, [7]. This approach assumes that a bank account enables poor households to perform important financial functions such as saving money safely outside the house, accessing credit, making loan or premium payments, and transferring money [8]. Thus, in this framework, a bank account should determine access to and usage of many other financial services [9].

The Central government has been encouraging the state governments to make wage payment through bank and post office accounts of wage seekers. Under the new system of financial inclusion 40, 27,196 MGNREGA workers accounts have been opened and about $84 \%$ of wages i.e. close to Rs 38,546 lakh have been disbursed through these accounts up to November 2012 - 13 accounting for $70 \%$ of the expenditure under the 
programme in Odisha. The details of the number of account in banks and post office and amount of wage payment through bank and post office have been given in the table 3 given below.

Table 3: Number of MGNREGA bank and post office accounts and amount disbursed in Odisha

\begin{tabular}{|c|c|c|c|c|c|}
\hline & 2008-09 & $2009-10$ & $2010-11$ & 2011-12 & $2012-13$ \\
\hline $\begin{array}{l}\text { No. of bank and post office } \\
\text { account opened }\end{array}$ & $1,830,009$ & $25,97,403$ & $57,26,707$ & $37,05,424$ & $40,27,196$ \\
\hline $\begin{array}{l}\text { Total Amount Disbursed through } \\
\text { Bank and Post Office (Rs.in lakhs) }\end{array}$ & 22,929 & 56,603 & 83,590 & 54,898 & 38,546 \\
\hline
\end{tabular}

Source: www.nrega.ac.in [10]

It is shown in the table 3 that numbers of MGNREGA accounts are increasing except in year 2011-12 which show a decline but again in the next year it increases. Thus this shows that government has taken a right direction in achieving financial inclusion by taking the help of MGNREGA. But with respect to amount disbursed through these accounts success has been achieved in initial years but in last two years a downward trend is being realized. This shows some problems in disbursement even though there has been an increase in number of account. Only opening a account does not mean financial inclusion rather there should financial transaction through these account to achieve financial inclusion in real sense.

An inter-district level analysis will throw more light on performance of a programme at micro level. So an inter district analysis in Odisha will shed more light on the progress of MGNREGA in ensuring financial inclusion through opening of bank or post office account and wage payment transaction by these accounts. Table 4 shows number of bank and post office account opened under MGNREGA in different districts of Odisha.

Table 4: Total number of bank and post office account opened under MGNREGA in Odisha and annual average growth rate during 2008-13.

\begin{tabular}{|c|c|c|c|c|c|c|}
\hline District & 2008-09 & $2009-10$ & 2010-11 & 2011-12 & $2012-13$ & $\begin{array}{c}\text { annual average growth } \\
\text { rate }\end{array}$ \\
\hline Bolangir & 67148 & 73551 & 81207 & 81207 & 103172 & 12 \\
\hline Boudh & 16216 & 32036 & 31793 & 38018 & 62148 & 45 \\
\hline Deogarh & 21957 & 24864 & 25698 & 26544 & 38892 & 17 \\
\hline Dhenkanal & 43301 & 100409 & 100409 & 291856 & 164541 & 70 \\
\hline Gajapati & 48177 & 66790 & 75131 & 82231 & 69714 & 11 \\
\hline Ganjam & 185479 & 271869 & 420794 & 411492 & 451755 & 27 \\
\hline Jharsuguda & 16591 & 16591 & 16591 & 42614 & 48632 & 43 \\
\hline Kalahandi & 106075 & 156404 & 162253 & 148746 & 182885 & 16 \\
\hline Kandhamal & 44084 & 115134 & 170491 & 176570 & 184121 & 54 \\
\hline Kendujhar & 86054 & 96012 & 98510 & 110536 & 280125 & 45 \\
\hline Koraput & 41877 & 102879 & 107986 & 95226 & 197223 & 61 \\
\hline Malkangiri & 34274 & 34274 & 34274 & 34274 & 34274 & 0 \\
\hline Mayurbhanj & 304337 & 304352 & 383252 & 383252 & 445768 & 11 \\
\hline Nabarangapur & 68036 & 117251 & 165093 & 97276 & 165812 & 36 \\
\hline Nuapada & 10059 & 39031 & 39041 & 87238 & 0 & 78 \\
\hline Rayagada & 132836 & 152321 & 160597 & 161983 & 169214 & 6 \\
\hline Sambalpur & 58782 & 95468 & 107357 & 114994 & 0 & -5 \\
\hline Sonepur & 42116 & 52051 & 52051 & 39010 & 80484 & 26 \\
\hline Sundargarh & 117247 & 184843 & 208209 & 185849 & 185849 & 15 \\
\hline Angul & 77644 & 112468 & 114860 & 230449 & 115397 & 24 \\
\hline Baleshwar & 49727 & 9541 & 81955 & 94668 & 138848 & 185 \\
\hline Bargarh & 94707 & 94710 & 95662 & 85440 & 99490 & 2 \\
\hline Bhadrak & 24168 & 41858 & 68979 & 90758 & 106653 & 47 \\
\hline Jajpur & 40283 & 91998 & 185406 & 133652 & 40059 & 33 \\
\hline Cuttack & 51527 & 54695 & 2411409 & 44612 & 157944 & 1118 \\
\hline Jagatsinghpur & 17206 & 24271 & 54162 & 63244 & 92068 & 57 \\
\hline Kendrapara & 9346 & 38496 & 113116 & 120938 & 125517 & 129 \\
\hline Khurda & 947 & 22564 & 24041 & 28953 & 18969 & 569 \\
\hline Nayagarh & 17203 & 39952 & 79416 & 116137 & 142521 & 75 \\
\hline Puri & 2605 & 30720 & 56964 & 87657 & 125121 & 315 \\
\hline
\end{tabular}

Source: compiled by author and www.nrega.ac.in [10]

It can be seen from table 4 that districts like Cuttack, Khurda, Puri, Baleswar, and Kendrapara are performing very well in achieving financial inclusion as more than $100 \%$ has been the annual average growth rate during 2008-13 with regard to opening a account. But some of districts like Rayagada, Bargarh,Bolangir, Deogarh Gajapati,Kalahandi,Mayurbhanj,Sundargarh where average annual growth rate during 2008-13 is less than $20 \%$.Even some districts like Sambalpur,Malkangiri , a zero/negative growth rate has been recorded. So 
now the question is why the performance of these districts is poor. Whether the problem is on part of government, bank or with people. This dilemma can be clear by knowing the amount of wage expenditure through bank/post office because only opening a account is not enough. It is necessary that wage payment should be through these accounts.

With much expectation Government has introduced MGNREGA wage payment through banks and post office account which will facilitate and help to speed up the financial inclusion. Table 5 and 6 sheds more light on existing problem and present a totally different picture. Those districts which were having very low average annual growth rate like Sambalpur, Malkangiri,Rayagada, Bargarh are showing great performance with regard to wage payment through bank/post office. More than $80 \%$ wages are disbursed through bank/post office. We could also satisfy ourselves by seeing 24 out of 30 districts have their wage payment through bank/post office.

Table 5: Expenditure on Wages and total amount disbursed through Bank and Post Office in Odisha under MGNREGA (Rs. In lakhs)

\begin{tabular}{|c|c|c|c|c|c|c|c|c|c|c|}
\hline & \multicolumn{2}{|c|}{ 2008-09 } & \multicolumn{2}{|c|}{$2009-10$} & \multicolumn{2}{|c|}{ 2010-11 } & \multicolumn{2}{|c|}{ 2011-12 } & \multicolumn{2}{|c|}{$2012-13$} \\
\hline Districts & $\begin{array}{l}\text { Expendi } \\
\text { ture on } \\
\text { Wages }\end{array}$ & $\begin{array}{c}\text { Total } \\
\text { Amount } \\
\text { Disburse } \\
\text { d }\end{array}$ & $\begin{array}{l}\text { Expend } \\
\text { iture on } \\
\text { Wages }\end{array}$ & $\begin{array}{c}\text { Total } \\
\text { Amount } \\
\text { Disburs } \\
\text { ed }\end{array}$ & $\begin{array}{l}\text { Expendi } \\
\text { ture on } \\
\text { Wages }\end{array}$ & $\begin{array}{c}\text { Total } \\
\text { Amou } \\
\text { nt } \\
\text { Disbur } \\
\text { sed }\end{array}$ & $\begin{array}{l}\text { Expenditu } \\
\text { re on } \\
\text { Wages }\end{array}$ & $\begin{array}{c}\text { Total } \\
\text { Amount } \\
\text { Disburs } \\
\text { ed }\end{array}$ & $\begin{array}{l}\text { Expenditu } \\
\text { re on } \\
\text { Wages }\end{array}$ & $\begin{array}{c}\text { Total } \\
\text { Amount } \\
\text { Disbursed }\end{array}$ \\
\hline Bolangir & $\begin{array}{c}2117.1 \\
1 \\
\end{array}$ & 1347 & 2688.49 & 2556 & 2780.95 & 2008 & 2649.96 & 2595 & 3482.75 & 1845 \\
\hline Boudh & 789.7 & 249 & 745.34 & 738 & 1163.71 & 766 & 1354.72 & 1306 & 1294.26 & 692 \\
\hline Deogarh & 553.09 & 347 & 650.52 & 572 & 774.19 & 385 & 545.98 & 492 & 817.51 & 298 \\
\hline Dhenkanal & 611.74 & 378 & 2034.53 & 1928 & 3078.47 & 2538 & 1542.55 & 2373 & 1194.11 & 683 \\
\hline Gajapati & $\begin{array}{c}1359.0 \\
1 \\
\end{array}$ & 625 & 2300.16 & 2203 & 2935.49 & 2180 & 1740.23 & 1708 & 1544.36 & 872 \\
\hline Ganjam & $\begin{array}{c}6454.5 \\
9 \\
\end{array}$ & 4439 & 5614.58 & 5587 & 5368.61 & 5365 & 3231.55 & 3181 & 6305 & 3977 \\
\hline Jharsuguda & 497.82 & 370 & 847.35 & 783 & 1368.9 & 1040 & 989.24 & 940 & 736.8 & 455 \\
\hline Kalahandi & $\begin{array}{c}1494.0 \\
1\end{array}$ & 308 & 1890.37 & 1877 & 3563.05 & 2669 & 2773.37 & 2684 & 3290.3 & 1481 \\
\hline Kandhamal & $\begin{array}{c}1539.6 \\
1\end{array}$ & 530 & 4110.23 & 4111 & 4336.96 & 3350 & 4672.03 & 4499 & 4152.43 & 1991 \\
\hline Kendujhar & $\begin{array}{c}1153.9 \\
1\end{array}$ & 917 & 2669.81 & 2626 & 6783.86 & 6413 & 3542.68 & 3409 & 3771.63 & 2254 \\
\hline Koraput & $\begin{array}{c}1709.3 \\
3\end{array}$ & 464 & 2302.6 & 2299 & 4479.12 & 4330 & 2745.13 & 2635 & 3192.53 & 1216 \\
\hline Malkangiri & $\begin{array}{c}1388.0 \\
5\end{array}$ & 997 & 1268.28 & 1238 & 3340.16 & 3196 & 1574.46 & 1579 & 1389.15 & 632 \\
\hline $\begin{array}{c}\text { Mayurbhan } \\
\mathrm{j}\end{array}$ & 5100.4 & 4602 & 5024.41 & 4889 & 7325.14 & 6932 & 3961.8 & 3953 & 7356.03 & 2925 \\
\hline $\begin{array}{c}\text { Nabaranga } \\
\text { pur }\end{array}$ & $\begin{array}{c}1482.4 \\
4 \\
\end{array}$ & 426 & 3699.04 & 3697 & 6039.99 & 5933 & 2718.92 & 2625 & 3719.25 & 2386 \\
\hline Nuapada & $\begin{array}{c}1361.3 \\
7\end{array}$ & 155 & 546.46 & 525 & 1012.45 & 756 & 1378.53 & 1281 & 1364.14 & 2412 \\
\hline Rayagada & $\begin{array}{c}2248.7 \\
1\end{array}$ & 1917 & 2695.68 & 2377 & 4650.42 & 4129 & 2186.77 & 1924 & 2102.11 & 1208 \\
\hline Sambalpur & 847.14 & 312 & 1436.28 & 1308 & 3530.42 & 3254 & 1644.6 & 1417 & 984.98 & 401 \\
\hline Sonepur & $\begin{array}{c}1055.8 \\
6 \\
\end{array}$ & 361 & 1410.6 & 1306 & 2366.61 & 2068 & 1129.93 & 1078 & 1059.2 & 1153 \\
\hline Sundargarh & $\begin{array}{c}1850.1 \\
6 \\
\end{array}$ & 853 & 3694.27 & 3364 & 4247.75 & 3904 & 3331.34 & 3149 & 4716.24 & 1848 \\
\hline Angul & 846.81 & 688 & 1953.06 & 1791 & 2125.54 & 1915 & 986.7 & 978 & 1347.47 & 609 \\
\hline Baleshwar & $\begin{array}{c}1262.5 \\
1\end{array}$ & 937 & 789.76 & 774 & 1916.37 & 1732 & 1218.32 & 1215 & 2139.79 & 1274 \\
\hline Bargarh & 849.21 & 452 & 1744.54 & 1713 & 1681.94 & 1595 & 1186.08 & 1144 & 939.11 & 665 \\
\hline Bhadrak & $\begin{array}{c}1277.4 \\
8\end{array}$ & 387 & 709.13 & 630 & 1606.74 & 1427 & 881.31 & 873 & 2177.13 & 1793 \\
\hline Jajpur & $\begin{array}{c}1286.0 \\
1 \\
\end{array}$ & 162 & 3310.51 & 3301 & 3672.65 & 3309 & 612.18 & 575 & 941.01 & 608 \\
\hline Cuttack & 266.89 & 469 & 1757.84 & 1756 & 2880.51 & 2907 & 1219.02 & 1185 & 1616.78 & 1255 \\
\hline $\begin{array}{c}\text { Jagatsingh } \\
\text { pur }\end{array}$ & 130 & 77 & 673.39 & 591 & 2258.86 & 2005 & 731.03 & 762 & 1009.58 & 26 \\
\hline Kendrapara & 75.03 & 51 & 546.33 & 543 & 2671.03 & 2527 & 962.31 & 991 & 887.55 & 499 \\
\hline Khurda & 71.99 & 0 & 316.15 & 308 & 463.43 & 453 & 395.67 & 394 & 741.98 & 383 \\
\hline Nayagarh & 87.04 & 91 & 854.63 & 840 & 2995.72 & 2770 & 3261.4 & 3214 & 2753.68 & 1879 \\
\hline Puri & 43.34 & 18 & 387.22 & 372 & 1874.02 & 1734 & 753.95 & 739 & 1024.37 & 826 \\
\hline
\end{tabular}

Source: www.nrega.ac.in [10] 
Table 6: \% of wage expenditure and annual average percentage of wage expenditure (2008-13) disbursed through Bank and Post Office under MGNREGA in Odisha

\begin{tabular}{|c|c|c|c|c|c|c|}
\hline District & 2008-09 & $2009-10$ & $2010-11$ & 2011-12 & $2012-13$ & $\begin{array}{c}\text { annual average } \% \text { of wage } \\
\text { expenditure disbursed } \\
\text { through bank/post office }\end{array}$ \\
\hline Bolangir & 64 & 95 & 72 & 98 & 53 & 76 \\
\hline Boudh & 32 & 99 & 66 & 96 & 53 & 69 \\
\hline Deogarh & 63 & 88 & 50 & 90 & 36 & 65 \\
\hline Dhenkanal & 62 & 95 & 82 & 100 & 57 & 79 \\
\hline Gajapati & 46 & 96 & 74 & 98 & 56 & 74 \\
\hline Ganjam & 69 & 100 & 100 & 98 & 63 & 86 \\
\hline Jharsuguda & 74 & 92 & 76 & 95 & 62 & 80 \\
\hline Kalahandi & 21 & 99 & 75 & 97 & 45 & 67 \\
\hline Kandhamal & 34 & 100 & 77 & 96 & 48 & 71 \\
\hline Kendujhar & 79 & 98 & 95 & 96 & 60 & 86 \\
\hline Koraput & 27 & 100 & 97 & 96 & 38 & 72 \\
\hline Malkangiri & 72 & 98 & 96 & 100 & 45 & 82 \\
\hline Mayurbhanj & 90 & 97 & 95 & 100 & 40 & 84 \\
\hline Nabarangapur & 29 & 100 & 98 & 97 & 64 & 78 \\
\hline Nuapada & 11 & 96 & 75 & 93 & 100 & 75 \\
\hline Rayagada & 85 & 88 & 89 & 88 & 57 & 82 \\
\hline Sambalpur & 37 & 91 & 92 & 86 & 41 & 69 \\
\hline Sonepur & 34 & 93 & 87 & 95 & 100 & 82 \\
\hline Sundargarh & 46 & 91 & 92 & 95 & 39 & 73 \\
\hline Angul & 81 & 92 & 90 & 99 & 45 & 81 \\
\hline Baleshwar & 74 & 98 & 90 & 100 & 60 & 84 \\
\hline Bargarh & 53 & 98 & 95 & 96 & 71 & 83 \\
\hline Bhadrak & 30 & 89 & 89 & 99 & 82 & 78 \\
\hline Jajpur & 13 & 100 & 90 & 94 & 65 & 72 \\
\hline Cuttack & 100 & 100 & 100 & 97 & 78 & 95 \\
\hline Jagatsinghpur & 59 & 88 & 89 & 100 & 3 & 68 \\
\hline Kendrapara & 68 & 99 & 95 & 100 & 56 & 84 \\
\hline Khurda & 0 & 97 & 98 & 100 & 52 & 69 \\
\hline Nayagarh & 100 & 98 & 92 & 99 & 68 & 92 \\
\hline Puri & 42 & 96 & 93 & 98 & 81 & 82 \\
\hline
\end{tabular}

Source: compiled by author

Thus from above analysis it can be seen that district like Rayagada, Bargarh, Sambalpur, Malkangiri Bargarh,Bolangir, Deogarh Gajapati,Kalahandi,Mayurbhanj,Sundargarh can be considered to be low performing districts as they are having very low/negative(less than 20 percent) average annual growth rate in case of number of bank/post office account under MGNREGA though more than 70 percentage of wage payment are through these account. District like Baleshwar,Puri,Cuttack,Kendrapara,Khurda can be considered as high performing district where average growth rate in opening of number of account under MGNREGA is very high (more than 100 percent), some districts like Nayagarh,Nuapada,Dhekenal performance is up to mark (more than 70 percent )but district like Sambalpur, Malkangiri definitely requires government attention for its dismal performance. It seems that there are some issues because of which not much people has benefitted from the Scheme in those districts in terms of financial services from bank/post office. Those issues and possible solution to those issues are dealt in next section followed by conclusion.

\section{Issues Relating To Payment Of Wages Through Bank/Post Office And Policy Prescription}

It can be seen that though government has taken a very important step to speed up financial inclusion but result is far from expectation. Although this new system has been hailed as a foolproof, cost-effective solution to reduce leakages and to promote greater transparency, the transition was rushed and several complications with the new system are now becoming apparent. Following are some severe complication:

1. Delays in wage disbursement: The issue of delays in wage payments is one of the most serious problems with the system of bank payments. Reports from several states including Jharkhand, West Bengal, 
Chhattisgarh, Rajasthan, Madhya Pradesh, Uttar Pradesh and West Bengal indicate the problem of delayed payments and dwindling interest in employment under the MGNREGA is widespread across number of states even in Odisha.In khanddeula village of Betnoti block, of Odisha labourers were paid in September for work that had begun at the end of may and ended in middle of June [11].It is a well established argument that the coverage of banks and post offices in rural Odisha is patchy and as a consequence workers especially in remote parts of the state find it difficult to travel long distances to collect their wages causing delays in payments. An important cause of the severe delays in the disbursement of wages is the institutional incapacity of rural banks to handle the huge volume of accounts. The shortage of staff and technology is most acute in post offices where accounts are managed manually through log journals.

There are several bottlenecks associated with the different steps in the wage payment process: Filling the muster roll, measuring work and matching with attendance, preparing payment orders, sanctioning of cheques by officials and finally crediting of wages in workers accounts by the bank. Centre-state financial norms are not always clear and often mired in politics causing significant delays in the flow of funds from the central to state governments. Although such delays legally entitle workers to unemployment benefit, compensation has rarely been paid which is a clear violation of the Act.

2. Corruption: While the move of separating the implementation and payment agencies has countered the earlier forms of corruption such as siphoning of funds, some forms of embezzlement have persisted and some new forms have emerged. The first is through 'deception' where often the abhikarta (implementing agency) in collusion with the bank officials withdraws money from the accounts of workers without their knowledge. The second is through 'exploitation' where genuine workers withdraw their wages themselves but are forced to hand over part of their money to the contractor or sarpanch based on a pre-decided 'deal'. The third method is where workers 'collude' with the implementing agency and fake names are entered in muster roll on the basis of which wages are drawn. While the first type of misuse can be effectively dealt with through strict enforcement of certain minimum safeguards such as ensuring money is only withdrawn by the account holder.

The other two types of misappropriation are perhaps more difficult to counter because they are borne out of an essentially feudal, exploitative set up in which rural bank function. Taking strict action against such corruption, the government has restated that unfair practices in the system of wage payments will be punishable under section 25 of the Act. However the record for invoking this clause has been quite abysmal. While enforcing this penalty clause which allows for a fine up to Rs 1000 will ensure accountability to some extent, there is a pressing need to restore transparency safeguards already built into the act. Public scrutiny of wages through reading out muster rolls and regular updating of job cards needs to be reinstated. This is a powerful practice because it enables workers to verify their attendance and monitor wage payments themselves, thereby curbing corruption.

The switch to bank payments has without a doubt provided substantial protection against misuse and is a critical step towards ensuring greater accountability in the disbursement of wages under the MGNREGA. However, the issue of delays in wage payment needs to be tackled swiftly by both streamlining processes and mechanisms under the system of bank payments as well as reinforcing traditional safeguards.

According to the Report of the Central Employment Guarantee Council's "Working Group on Wages" 2010, the transition to wage payments through banks and post offices (POs) had been a step forward in many ways, notably by enabling millions of people to open bank or post office accounts (something they would have found difficult to do earlier), and by making it much hard for corrupt middlemen to misuse wage funds.

However, the transition was too rushed, and caused much chaos in its initial stage. Even today, there are serious problems associated with the system of wage payments through banks and post offices.

It is also important to acknowledge that the payment of wages through banks and post offices is not a fool-proof protection against fraud. In areas with exploitative social relations, it is not uncommon for corrupt middlemen to control the bank/PO accounts of MGNREGA workers and use them to siphon off wage funds.

Even when MGNREGA workers operate their own accounts, bribes are sometimes extracted from them by bank or (especially) post office employees. While there is some evidence that MGNREGA workers are rapidly learning to avoid this sort of exploitation, the problem is far from resolved. Further, the entire system remains vulnerable to collusive arrangements whereby middlemen siphon off MGNREGA wage funds from bank accounts in collusion with workers, or fictitious workers. It is very important not to over-rely on bank/PO wage payments to avoid corruption, and to consolidate other transparency safeguards such as the transparency of Muster Rolls, maintenance of Job Cards, activation of Vigilance Committees, social audits, etc.

Thus, much work remains to be done to consolidate and streamline the entire system of wage Payments through banks and post offices. The following steps can be taken to streamline the system:

1. Awareness drives to ensure that MGNREGA workers understand the system and are able to operate their own accounts without being exploited.

2. Improved record-keeping, e.g. use of well-designed Payment Orders. 
3. Accelerated transition to computerized generation of Payment Orders and Wage Slips from the Muster Rolls.

4. Capacity building (including computerization) in banks, and particularly in post offices, especially in remote areas.

5. "Know Your Customer" (KYC) guidelines should be strictly implemented and monitored when it comes to bank payments of MGNREGA wages - including prompt issue of passbooks and updating of passbook when wage are disbursed.

6. The MGNREGA Guidelines should clearly indicate that separate individual accounts for men and women (and not joint accounts) should be the norm.

7. The 'Business Correspondent Model' which is currently being rolled out by the government is an attempt to address this problem of delayed payments and ensure that the rural poor have timely access to financial services. How this works is that the business correspondent (BC) would, on behalf of the banks, for a commission, deliver financial services to 'clients' though appropriate technology like handheld computer devises. Caution is required with related innovations such as the use of smart cards, biometric identification, etc., to facilitate wage payments.

\section{Conclusion}

The direct transfer of wages into workers' bank accounts is a substantial protection against embezzlement, provided that banking norms are adhered to and that workers are able to manage their own accounts. MGNREGA workers had a fairly positive attitude towards bank payments, and an interest in learning how to use the banking system [12]. While the rushed transition to bank payments (in 2008) created a certain amount of confusion and chaos, the prospects of effective use of banks as a payment agency for MGNREGA seems reasonably good. Further MGNREGA wage payment through bank and post office also helps to speed up financial inclusion and it could create wonderful impact in the rural areas, provided it is properly implemented with maximum participation of the local people. As seen in the inter-district analysis of Odisha both high and low performing districts are doing well with wage disbursement as more than 70 percentage of wage payment are done through these account . So problem lies with slow growth rate of opening and transaction through these bank/post office account in some district which deserves serious attention. Further we should try to achieve cent percent wage payment though bank/post office. The top-down approach, first of all, has to be abandoned. Mechanisms have to be developed to ensure that the spirit of the Act is executed and the poor people are respected. Any complaints of willful negligence of the concerned officials should be seriously dealt with and severe punishments should be imposed on the errant. Improving the system of bank payment can only go part of the way towards the end that is financial inclusion .Building a culture of transparency and accountability in the implementation of MGNREGA remains extremely important. So we have a long way to go to achieve 100 percent financial inclusion. A whole-hearted effort is called for from all the corners of the society, viz., banks, beneficiaries and regulators in order to make financial inclusion more meaningful and effective

\section{References}

[1] Beck, T., A. Demirgüç-Kunt, and M. S. Martinez Peria.,Banking Services for Everyone? Barriers to Bank Access and Use around the World, World Bank Economic Review 22(3), 2008, 397-430.

[2] Caskey, J., C. R. Duran, and T. M. Solo, The Urban Unbanked in Mexico and the United State, Policy Research Working Paper 3835, World Bank, 2006, Washington, DC.

[3] Dupas, P., and J. Robinson, Savings Constraints and Microenterprise Development: Evidence from a Field Experiment in Kenya, NBER Working Paper 14693, National Bureau of Economic Research, Cambridge, 2009, MA.

[4] Department of statistics, Financial Access Survey, IMF http://fas.imf.org/ as assessed on 8/8/2013

[5] Chattopadhyay S K, Financial Inclusion in India: A case-study of West Bengal, RBI working paper series,WPS(DEPR):8/2011

[6] Das V, NREGA -Orissa Experience struggle for wages and survival of the fittest, Catalyst, VolVII, no.2, 2009, 7-8, 20.

[7] Beck, Thorsten and Augusto de la Torre., The Basic Analytics of Access to Financial Services, Policy Research Working Paper No. WPS4026, World Bank, Washington DC, October 2006.

[8] Mohan R, Economic Growth, Financial Deepening and Financial Inclusion, Annual Bankers' Conference, BIS Review 113/2006, Hyderabad http://rbidocs.rbi.org.in/rdocs/Speeches/PDFs/73697.pdf as assessed on 6/8/2013.

[9] Littlefield E, Helms B and Porteous, D, Financial Inclusion 2015: Four Scenarios for the Future of Microfinance, GAP Focus Note No 39,2006

[10] www.nrega.ac.in

[11] Vanaik, A., and Siddhartha, Bank Payments: End of Corruption in NREGA?, Economic and Political Weekly, vol.43,no.17,2008,33,35-39

[12] Adhikari, A., and Bhatia, K., NREGA Wage Payments: Can We Bank on the Banks, Economic and Political Weekly, Vol XLV NO $1,2010,30-37$. 